OPEN ACCESS

Edited by:

Anirban Basu,

National Brain Research Centre

(NBRC), India

Reviewed by:

Balaji Kithiganahalli,

Indian Institute of Science (IISC), India

Dipshikha Chakravortty,

Indian Institute of Science (IISc), India

*Correspondence:

Sangita Mukhopadhyay

sangita@cdfd.org.in

${ }^{t}$ These authors have contributed equally to this work and share first authorship

Specialty section: This article was submitted to Clinical Microbiology, a section of the journal

Frontiers in Cellular and Infection Microbiology

Received: 21 January 2021 Accepted: 09 June 2021 Published: 01 July 2021

Citation:

Srivastava S, Abraham PR and Mukhopadhyay S (2021) Aptamers: An Emerging Tool for Diagnosis and

Therapeutics in Tuberculosis. Front. Cell. Infect. Microbiol. 11:656421.

doi: 10.3389/fcimb.2021.656421

\section{Aptamers: An Emerging Tool for Diagnosis and Therapeutics in Tuberculosis}

\author{
Shruti Srivastava ${ }^{1 \dagger}$, Philip Raj Abraham ${ }^{2 \dagger}$ and Sangita Mukhopadhyay ${ }^{1 *}$ \\ 1 Laboratory of Molecular Cell Biology, Centre for DNA Fingerprinting and Diagnostics (CDFD), Hyderabad, India, \\ 2 Unit of OMICS, ICMR-Vector Control Research Centre (NCRC), Puducherry, India
}

Tuberculosis (TB) has been plaguing human civilization for centuries, and currently around one-third of the global population is affected with TB. Development of novel intervention tools for early diagnosis and therapeutics against Mycobacterium tuberculosis (M.tb) is the main thrust area in today's scenario. In this direction global efforts were made to use aptamers, the chemical antibodies as tool for TB diagnostics and therapeutics. This review describes the various aptamers introduced for targeting M.tb and highlights the need for development of novel aptamers to selectively target virulent proteins of $M$.tb for vaccine and anti-TB drugs. The objective of this review is to highlight the diagnostic and therapeutic application of aptamers used for tuberculosis. The discovery of aptamers, SELEX technology, different types of SELEX development processes, DNA and RNA aptamers reported for diseases and pathogenic agents as well have also been described in detail. But the emphasis of this review is on the development of aptamers which can block the function of virulent mycobacterial components for developing newer TB vaccine candidates and/or drug targets. Aptamers designed to target M.tb cell wall proteins, virulent factors, secretory proteins, or combination could orchestrate advanced diagnosis and therapeutic measures for tuberculosis.

Keywords: aptamer, Systematic Evolution of Ligands by Exponential Enrichment, Mycobacterium tuberculosis, tuberculosis, diagnosis, therapeutics

\section{INTRODUCTION}

Tuberculosis (TB) caused by Mycobacterium tuberculosis (M.tb) is a leading cause of death from a single infectious agent worldwide. World health organization (WHO) estimates that 10 million people died of TB in 2018. In this scenario, development of novel approaches for early diagnosis and therapeutics against M.tb is main thrust area. Since conventional control measures have been partially successful in keeping TB epidemic under check, identification of biomolecules which can block the function of virulent mycobacterial components is crucial for developing newer TB vaccine candidates and/or drugs. In this context, aptamers, also known as 'chemical antibodies', that specifically recognize $M . t b$ or inhibit the function of its virulent proteins are being developed (Chen et al., 2007). The aptamers are reported 30 years ago in 1990 (Tuerk and Gold, 1990; Ellington and Szostak, 1992). Aptamers are single-stranded DNA or RNA oligonucleotides that are capable of binding target molecules with high specificity and affinity. Structurally, they are relatively small 
biomolecules (ranging from 20 to 60 nucleotides) and mimic antibodies as they specifically bind to their targets. In comparison to antibodies, they have shorter generation time, lower manufacturing cost, higher modifiability, better thermal stability, higher target potential, and most importantly, no batch-to-batch variability. Due to multiple advantages over antibodies, they are being used as diagnostics, biosensors, and targeted therapeutics (Zhang et al., 2018) and are touted as a replacement for the use of antibodies in ELISA (Toh et al., 2015). In this article, we review the discovery of aptamers with special emphasis on how they are useful for diagnosis and therapeutic purposes against M.tb.

\section{SELEX: AN ART OF APTAMER SYNTHESIS}

Aptamers can be synthesized in large amounts as they are structurally stable for longer storage without or with minimal loss in activity. The procedure of in vitro synthesis of aptamers is known as "Systematic Evolution of Ligands by Exponential enrichment (SELEX)" (Stoltenburg et al., 2007). Aptamer generation is a long and exhaustive process. Conventionally, an oligonucleotide library contains a pool of 50-90 single-stranded random nucleotide sequences bordered by primer binding sites flanking at both ends. The mechanism of aptamer generation involves the following steps: (i) generation of random library of 1014-1016 single stranded oligonucleotides, (ii) incubation of oligonucleotides with its target, (iii) separation of bound oligonucleotides from unbound ones, (iv) selection of specific oligonucleotides, amplification by PCR (DNA aptamers) or RT -PCR (RNA aptamer), and (v) finally characterization of aptamer by sequencing (Figure 1). For the synthesis of RNA aptamer library, single-stranded DNA library having T7 RNA polymerase promoter sequence at $5^{\prime}$-region is generated. Such single-stranded DNA library is converted to double-stranded DNA, and in vitro transcription is performed to generate the desired RNA aptamers. All the steps are repeated till the desired oligonucleotide (or aptamer) with high binding affinity is obtained. Once the desired clones are obtained, they are further optimized to maximize the function. They are truncated or reduced in size to achieve minimal aptamer length with maximum binding affinity for the target. The preferred optimal length for aptamers is 15-45 nucleotides with molecular weight of $\sim 5-15 \mathrm{kDa}$. Aptamers bind to their targets with pico to micromolar binding affinity. In recent times, various types of SELEX processes have been developed for specific purposes (Table 1). SELEX process-generated aptamers are non-modified, and they are further subjected to various modifications at sugar moiety, phosphate modifications, nucleoside modification, and capping modifications. Some of the examples of modifications are; $2^{\prime}$-fluoro $\left(2^{\prime}\right.$-F) ribose, $2^{\prime}$-amino $\left(2^{\prime}\right.$ $\mathrm{NH} 2$ ) ribose, $2^{\prime}$-O-methyl (2'-OMe) ribose (Figure 2) (Maier and Levy, 2016). "Slow off-rate modified aptamers-(SOMAmers)" are new class of aptamers where deoxyribose thymine (dT) bases are replaced by deoxyribose uridine $(\mathrm{dU})$ base at $5^{\prime}$ position in the heterocyclic ring in oligonucleotide pool. Several replacements can be made at $5^{\prime}$ position to generate a vast range of aptamers with different binding affinity and kinetics properties increasing the possibilities of finding suitable aptamer (Maier and Levy, 2016). Naturally occurring nucleotides are D-oligonucleotide, and they form right-handed helix. Mirror image aptamers (spiegelmers) are

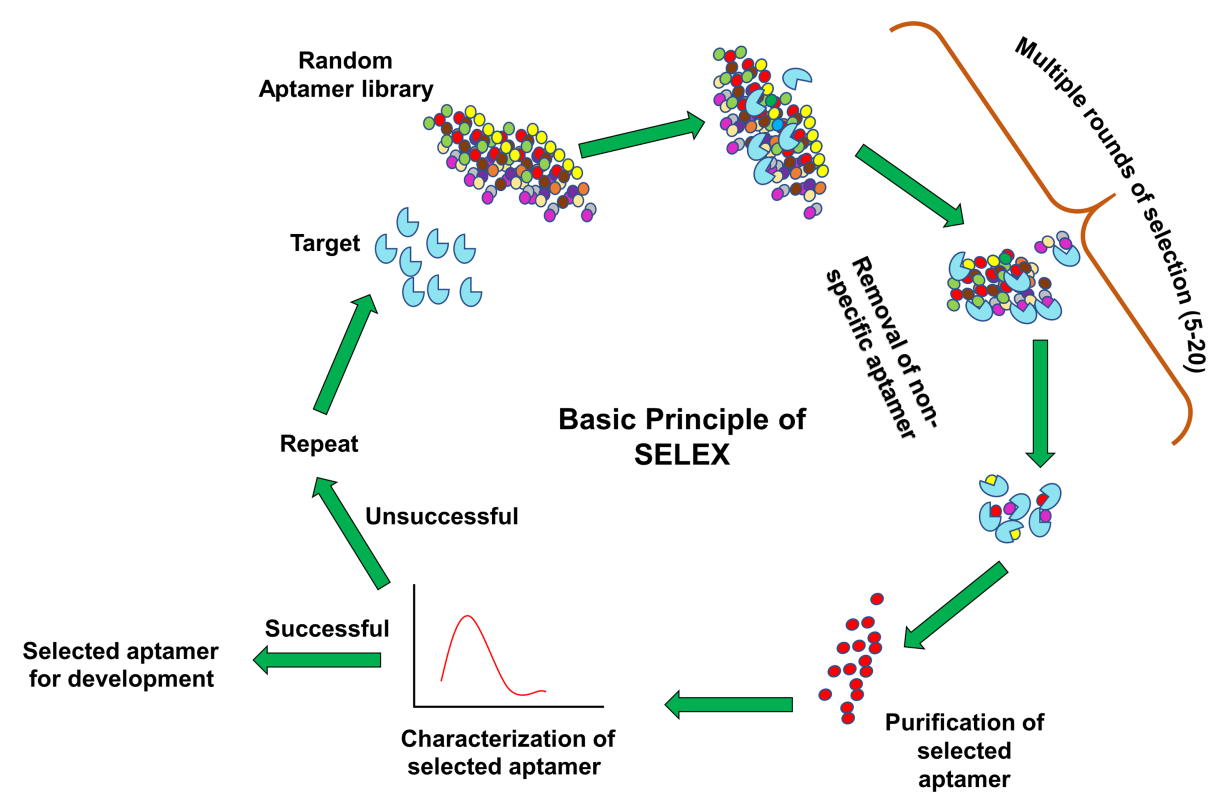

FIGURE 1 | Systematic evolution of ligands by exponential enrichment (SELEX) procedure. A library of aptamers with random oligonucleotides is incubated with target. Unbound aptamers are washed off during multiple round selection. The specific aptamer is enriched from the pool and subjected to various bioanalytical and biological assays. Aptamers are either further developed for several applications like therapeutics and diagnostics (successful) or again feed into the same SELEX cycle (unsuccessful). 
TABLE 1 | Types of SELEX development processes.

\begin{tabular}{|c|c|c|c|}
\hline S. No. & Type & Description & Reference \\
\hline 1. & Negative SELEX & For removal of non-specific aptamers & Ellington and Szostak 1992 \\
\hline 2. & Counter SELEX & $\begin{array}{l}\text { For removal of cross-reactive aptamers by incubating them } \\
\text { targets obtained from related species }\end{array}$ & Jenison, 1994 \\
\hline 3. & Genomic SELEX & $\begin{array}{l}\text { For the identification of binding } \\
\text { motif present in the genome of an organism }\end{array}$ & Singer et al., 1997 \\
\hline 4. & In vivo SELEX & $\begin{array}{l}\text { Aptamers are generated in vivo, inside the cell and then } \\
\text { characterized }\end{array}$ & Coulter et al., 1997 \\
\hline 5. & Chimeric SELEX & $\begin{array}{l}\text { In this method, well- characterized aptamers are fused together so that the resulting aptamer } \\
\text { can bind to different targets (one aptamer can recognise two or more different } \\
\text { targets) }\end{array}$ & Burke and Willis, 1998 \\
\hline 6. & Cell-SELEX & $\begin{array}{l}\text { For the development of aptamers which recognise markers present } \\
\text { in whole cell }\end{array}$ & Homann and Goringer, 1999 \\
\hline 7. & Indirect SELEX & $\begin{array}{l}\text { In this SELEX method, the } \\
\text { binding of aptamers with their targets are metal-ion dependent }\end{array}$ & Kawakami et al., 2000 \\
\hline 8. & Photo- SELEX & $\begin{array}{l}\text { In this method, nucleotides are light-sensitive and irradiation with UV rays is employed to } \\
\text { select the specific aptamer-target } \\
\text { from the pool }\end{array}$ & Golden et al., 2000 \\
\hline 9. & Toggle SELEX & For identification of cross- reactive aptamers by using toggled targets & Bianchini et al., 2001 \\
\hline 10. & Tailored SELEX & $\begin{array}{l}\text { Aptamers often contain primer- hybridization site. Introduction of cleavable primer } \\
\text { hybridization site in aptamers will select for primer-free-aptamers. }\end{array}$ & Vater et al., 2003 \\
\hline 11. & $\begin{array}{l}\text { CE (Capillary electrophoresis)- } \\
\text { SELEX }\end{array}$ & $\begin{array}{l}\text { This process selects high affinity aptamers in a few cycles }(2-4) \\
\text { thus shortens the aptamer selection process }\end{array}$ & $\begin{array}{l}\text { Mendonsa and Bowser, 2004; } \\
\text { Mosing and Bowser } 2009\end{array}$ \\
\hline 12. & FluMag SELEX & Targets are tagged with fluorophores & Stoltenburg et al., 2005 \\
\hline 13. & $\begin{array}{l}\text { Target expressed on cell } \\
\text { surface- SELEX (TECS- } \\
\text { SELEX) }\end{array}$ & $\begin{array}{l}\text { In this method, a cell is engineered to express a recombinant protein which will be used as } \\
\text { target protein for } \\
\text { aptamer development }\end{array}$ & Ohuchi et al., 2006 \\
\hline 14. & Nanoselection based SELEX & $\begin{array}{l}\text { One step method to isolate } \\
\text { aptamers using fluorescence and atomic force microscopy }\end{array}$ & Peng et al., 2007 \\
\hline 15. & MonoLEX & $\begin{array}{l}\text { Column chromatography and pyrosequencing is used to select } \\
\text { specific aptamer sequences }\end{array}$ & Nitsche et al., 2007 \\
\hline 16. & Microfluidic SELEX & Selection of aptamers are performed on a microfluidic chip & Cho et al., 2010. \\
\hline 17. & High- throughput SELEX & $\begin{array}{l}\text { In this method, high-throughput DNA sequencing and advanced bioinformatic analysis is } \\
\text { coupled } \\
\text { for aptamers selection }\end{array}$ & Hoon et al., 2011 \\
\hline 18. & Particle display SELEX & Flow cytometry based method for aptamer selection & Wang et al., 2014 \\
\hline 19. & Hi-fidelity SELEX & $\begin{array}{l}\text { Digital-PCR is used to intensify } \\
\text { the SELEX selection and development }\end{array}$ & Ouellet et al., 2015 \\
\hline 20. & Isogenic cell SELEX & $\begin{array}{l}\text { Aptamers are first selected against targets overexpressed on isogenic cell line, then counter- } \\
\text { selected against microRNA } \\
\text { mediated silencing of targets }\end{array}$ & Takahashi et al., 2016 \\
\hline
\end{tabular}

L-oligonucleotides, and they form left-handed helix. For spiegelmer generation, first conventional D-oligonucleotides are selected against mirror-image target. The selected D-oligonucleotides are chemically synthesized in reverse configuration as Loligonucleotides (Figure 2) (Vater and Klussmann, 2015). Suitable modifications can be incorporated either during selection process (SELEX) or post-selection (post-SELEX) step. Nonmodified aptamers are generally less stable and immunogenic than modified aptamers. Modifications prevent aptamers from nuclease-mediated degradation, increase binding affinity, and allow coupling with other molecules, drugs, or nanoparticles (Smith and Zain, 2019). After initial modification, aptamers go through several analytical assays for the assessment of the effect of modification on their binding affinity with target. Final aptamer product is different from the initial one and may possess single or multiple modifications in its structure. Aptamers are studied extensively for their pharmacological kinetics, toxicological feature, metabolism, and physiological clearance (Li et al., 2017; Smith and Zain, 2019).

\section{APPLICATIONS OF APTAMER}

Applications of SELEX and aptamer platform can be used for both diagnosis and drug delivery. In recent times, several research articles have reported the generation of aptamers against microbial pathogens and diseases (Table 2) (Cho et al., 2011; Hong and Sooter, 2015; Nimjee et al., 2017). Trypanosama cruzi is a blood-borne parasite and known to cause Chagas disease. RNA aptamer generated using whole cell SELEX method was able to detect $T$. cruzi trypomastigotes in the blood (Nagarkatti et al., 2012). Aptamers can easily be coupled with magnetic bead and fluorescent molecule. Exploring this ability, DNA aptamer-based sandwich assay was developed to detect soluble protein of Leishmania major (Bruno et al., 2014). Plasmodium lactate dehydrogenase (PLDH) and Plasmodium falciparum glutamate dehydrogenase (PfGDH) convert a bluedye Resazurin to Resorufin (pink). Magnetic bead-coated aptamers were developed to capture and separate PLDH, PfGDH from serum. The conversion from blue to pink color 
A<smiles></smiles>

$\mathbf{F}$

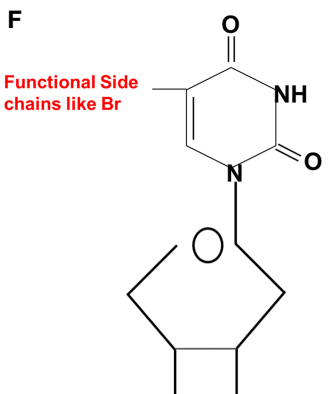<smiles></smiles>

G

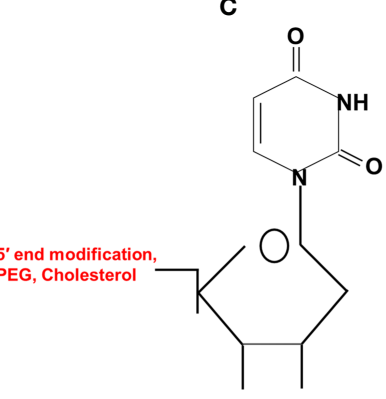

D

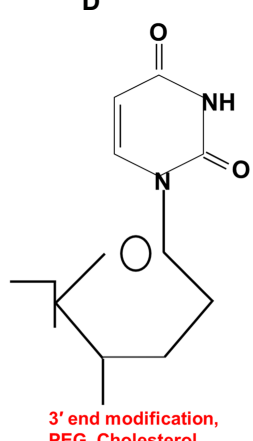

E

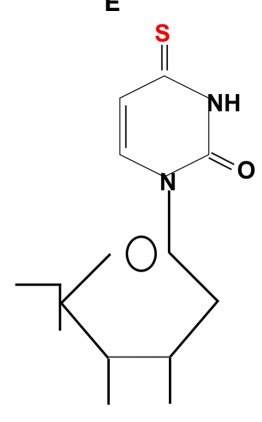

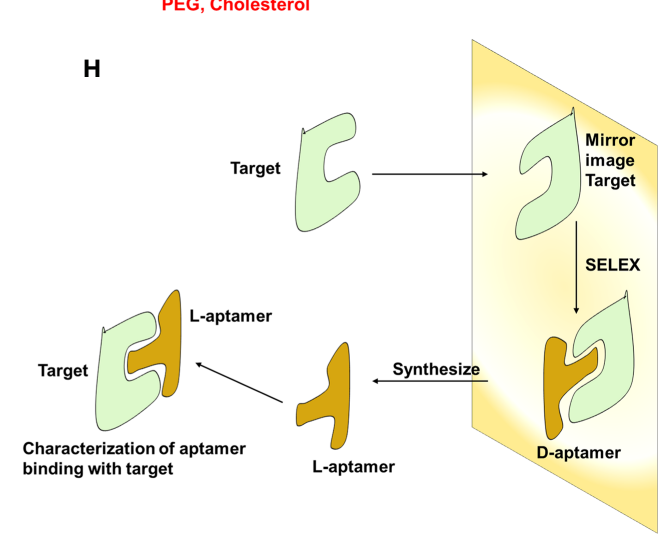

FIGURE 2 | Different types of modifications in aptamers. Chemical modifications at 2' position (A, B), 5' and 3' (C, D) ends of the sugar component, replacement of oxygen (O) with sulfur $(\mathbf{S}) \mathbf{( E )}$, incorporation of functional chains $\mathbf{( F )}$ or benzyl or naphthyl group (G) at the nitrogenous base. Generation of Spiegelmers (H). Aptamers are generated against target having mirror image configuration. Aptamers that bind to mirror image configuration of target are selected, PEG, polyethylene glycol; Br, bromine; F, fluorine.

was measured using either spectrophotometer or by qualitative visual interpretation. This is a low cost, portable, user-friendly diagnostic test (Singh et al., 2019). Salmonella sp. contamination is responsible for food-borne infections. Therefore, the detection of Salmonella sp. in contaminated food is a critical preventive measure in public health. By coupling 6-carboxyfluorescein (FAM), 27-nucleotide aptamer (LA27) was developed to detect LPS from Salmonella typhimurium (Ye et al., 2019). Also, aptamer-modified magnetic multifunctional nanoprobe (APTFMNP) was developed to detect $S$. typhimurium in milk, serum, and urine (Li et al., 2018). DNA-based aptamer to detect tularemia antigen from different subspecies of Francisella tularensis was designed at the Air Force research laboratory of USA. It was found that novel anti-tularemia aptamer cocktail can be used as a detection reagent for a potential biological warfare agent like F. tularensis (Vivekananda and Kiel, 2006).

The first aptamer approved for use as therapy in humans was a RNA-based molecule (macugen, pegaptanib) which is administered locally to treat age-related macular degeneration (AMD) by targeting vascular endothelial growth factor. Macugen received FDA approval in December 2004 for the treatment of AMD (Ng et al., 2006). RB006 aptamer binds to factor IXa and specifically blocks the conversion of factor X to factor Xa (Nimjee et al., 2005). Conversion of factor X to factor $\mathrm{Xa}$ is an important step in prothrombin assembly and thrombin generation. Hemophilia is a genetic disorder which causes defective intrinsic blood coagulation pathway. In hemophilia, coagulation factor VII and factor IX are deficient. Aptamer ARC19499 binds to tissue factor pathway inhibitor (TFPI), a negative regulator of extrinsic pathway, allowing the initiation of extrinsic coagulation pathway (Waters et al., 2011). AXL is a tyrosine kinase receptor overexpressed in solid tumor types. Aptamer GL21.T conjugated with an anti-tumor microRNA, let-7g, was injected via intravenous route in mice. A decrease in tumor growth was noticed in mice with A549 $\left(\mathrm{Axl}^{+}\right)$-Luc tumor xenograft (Esposito et al., 2014). Cytotoxic T cell antigen-4 (CTLA-4) is a cell surface receptor that decreases the immune reaction against tumors. Tetramer-RNA aptamer could inhibit CTLA-4 function in mice B16/F10.9 melanoma allograft model when injected intraperitoneally (Santulli-Marotto et al., 2003).

It is known that human immunodeficiency virus (HIV) attacks $\mathrm{CD}^{+}{ }^{+} \mathrm{T}$-cells, macrophages, and dendritic cells. An incapacitated immune system fails to protect humans and leads to development of acquired immunodeficiency syndrome (AIDS). Gp120 is a glycoprotein of HIV virus that binds to $\mathrm{CD} 4^{+}$ $\mathrm{T}$-cell receptor and invades the host. A novel dual inhibitory function-based anti-gp120 aptamer-siRNA chimera (A-1 and B68) could bind to gp 120 , thus preventing the viral entry in $\mathrm{CHO}$ cell line (Zhou et al., 2011). A modified thioaptamer, R12-2, 
TABLE 2 | Aptamers reported for microbial pathogens and diseases.

\begin{tabular}{|c|c|c|c|}
\hline S. No. & Target & Diseases or Pathogenic agent & References \\
\hline \multicolumn{4}{|c|}{ DNA aptamer } \\
\hline 1. & AS1411 & Acute myeloid leukemia & Ireson and Kelland, 2006 \\
\hline 2. & SARS-CoV N protein & Pathogenic agent & Cho et al., 2011 \\
\hline 3. & E. coli K88 & Pathogenic agent & Hong and Sooter, 2015 \\
\hline 4. & Salmonella Paratyphi A & Pathogenic agent & Hong and Sooter, 2015 \\
\hline 5. & Listeria monocytogenes & Pathogenic agent & Hong and Sooter, 2015 \\
\hline 6. & Shigella dysenteriae & Pathogenic agent & Hong and Sooter, 2015 \\
\hline 7. & Streptococcus mutans & Pathogenic agent & Hong and Sooter, 2015 \\
\hline 8. & Francisella tularensis subspecies(subsp.) japonica bacterial antigen & Pathogenic agent & Hong and Sooter, 2015 \\
\hline 9. & HIV reverse transcriptase & Pathogenic agent & Hong and Sooter, 2015 \\
\hline 10. & Dengue virus type-2 envelope protein domain III & Pathogenic agent & Hong and Sooter, 2015 \\
\hline 11. & $\begin{array}{l}\text { HCV envelope surface } \\
\text { glycoprotein E2 }\end{array}$ & Pathogenic agent & Hong and Sooter, 2015 \\
\hline 12. & Avian influenza $\mathrm{H} 5 \mathrm{~N} 1$ & Pathogenic agent & Hong and Sooter, 2015 \\
\hline 13. & $\begin{array}{l}\text { Mycobacterium } \\
\text { tuberculosis H37Rv }\end{array}$ & Pathogenic agent & Hong and Sooter, 2015 \\
\hline 14. & ARC1772 & Thrombosis & Nimjee et al., 2017 \\
\hline 15. & PTK7 aptamer & Leukemia & Nimjee et al., 2017 \\
\hline 16. & Nu172 & Anticoagulation & Maimaitiyiming et al., 2019 \\
\hline 17. & E10030 & $\begin{array}{l}\text { Age-related macular } \\
\text { degeneration (AMD) }\end{array}$ & Maimaitiyiming et al., 2019 \\
\hline 18. & N55 & Atherosclerosis & Sola et al., 2020 \\
\hline 19. & GBI-10 & In several types of tumors & Sola et al., 2020 \\
\hline 20. & SQ-2 & $\begin{array}{l}\text { Pancreatic ductal } \\
\text { adenocarcinoma (PDAC) }\end{array}$ & Sola et al., 2020 \\
\hline \multicolumn{4}{|c|}{ RNA aptamer } \\
\hline 21. & $\mathrm{~A} 9$ and $\mathrm{A} 10$ & Prostate cancer & Nimjee et al., 2017 \\
\hline 22. & $\begin{array}{l}\text { RNA } 14-16 \text { against } \\
\text { p68, helicase }\end{array}$ & Liver metastasis & Nimjee et al., 2017 \\
\hline 23. & Pegaptanib & AMD & Nimjee et al., 2017 \\
\hline 24. & ARC1905 & AMD & Maimaitiyiming et al., 2019 \\
\hline 25. & ARC19499 & Hemophilia & Maimaitiyiming et al., 2019 \\
\hline 26. & $\mathrm{NOX}-\mathrm{H} 94$ & Anemia & Maimaitiyiming et al., 2019 \\
\hline 27. & EYE001 & AMD & Maimaitiyiming et al., 2019 \\
\hline 28. & MRP1Apt & Melanoma cancer stem cells & Sola et al., 2020 \\
\hline 29. & A1 & Breast cancer cells & Sola et al., 2020 \\
\hline 30. & G-3 & HIV infection blockade & Sola et al., 2020 \\
\hline 31. & P30-10-16 & $\begin{array}{l}\text { Influenza B virus infection } \\
\text { blockade }\end{array}$ & Sola et al., 2020 \\
\hline 32. & PB & Prostate cancer & Sola et al., 2020 \\
\hline 33. & GL21.T & Axl-dependent cancers & Sola et al., 2020 \\
\hline \multicolumn{4}{|c|}{ SOMAmer: Slow-Off-rate-Modified-Aptamer } \\
\hline 34. & $\begin{array}{l}\text { Clostridium } \\
\text { difficile binary toxin (CdtA) }\end{array}$ & Pathogenic agent & Ochsner et al., 2014 \\
\hline 35. & $\begin{array}{l}\text { Proprotein convertase subtilisin/kexin } \\
\text { type } 9\end{array}$ & Disease & Gawande et al., 2017 \\
\hline 36. & $\begin{array}{l}\text { Vaccine antigen in the human papillomavirus (HPV) vaccine } \\
\text { Gardasil }\end{array}$ & Pathogenic agent & Trausch JJ et al., 2017 \\
\hline 37. & Glypican-3 SOMAmer & $\begin{array}{l}\text { Hepatocellular carcinoma } \\
\text { (HCC) }\end{array}$ & Duo et al., 2018 \\
\hline 38. & $\begin{array}{l}\text { Mycobacterium } \\
\text { tuberculosis }\end{array}$ & Pathogenic agent & Golichenari et al., 2018 \\
\hline
\end{tabular}

could specifically bind to HIV-1 RNaseH and inhibit viral replication in cell culture (Somasunderam et al., 2005). Ebola virus causes life-threatening hemorrhagic fever. Interferons mediate anti-viral function in humans, and VP35 protein of EBOLA inhibits the production of interferon regulatory factor 3 (IRF-3). Aptamers (1G8-14 and 2F11-14) could bind to interferon inhibitory domain (VP35IID) of VP35 protein, preventing the inhibition of IRF-3 in vitro (Basler et al., 2003; Cardenas et al., 2006). Staphylococcus aureus causes staphylococcal toxic shock syndrome (TSS), food-borne infection, and hospital-acquired infection. Enterotoxin B (SEB) from S. aureus activates T cells to generate cytokine storm. Aptamer A11 was developed to inhibit SEB activity, preventing cytokine storm (Wang et al., 2015). Anthrax disease is caused by a toxin secreted from Bacillus anthracis. An important component of anthrax toxin is a lethal factor (LF) that has protease activity. LF cleaves and activates mitogen-activated protein kinase kinase (MAPKK). ssDNA aptamer (ML12) prevents the protease activity of LF reducing its 
toxicity. It is being considered as a potential drug target against LF (Lahousse et al., 2018).

In addition, aptamers are also discovered as anti-cancer agents and used in the treatment of neurological disorders. One of the most promising aptamer, AS1411, induces growth inhibition in vitro and has shown activity against human tumor xenografts in vivo (Ireson and Kelland, 2006). Nucleolin is an external membrane protein over-expressed in cancerous cells. Aptamer AS1411 could bind to nucleolin, inhibiting its activity (Girvan et al., 2006; Soundararajan et al., 2008). AS1411 was the first drug identified to target nucleolin and used in the clinical trial of cancer treatment (Mongelard and Bouvet, 2010). Target specificity is an important trait of anti-cancer therapeutic. Prostate-specific membrane antigen (PSMA) is a biomarker for solid tumors. RNA aptamers (A9 and A10) against PSMA were identified. A polymeric nanoparticle with docetaxel drug-aptamer complex was able to reduce tumor growth in xenograft mice when injected intraperitoneally (Dassie et al., 2009). CT26 is a colon cancer cell line. In an effort to identify, specifically located aptamer, mice bearing intrahepatic tumor were injected Cy3-labeled RNA aptamers. Aptamers 14-16 were found to be localized in intrahepatic CT26 tumor tissues (Mi et al., 2010). Blood-brain barrier is major obstacle in the treatment of neurological diseases. Bioavailability of drugs is restricted in the brain. Aptamer pool of random RNA sequences was injected into tail vein of mice, and the localization of aptamers was checked in the brain. Aptamer A15 showed specific localization in the brain (Cheng et al., 2013). Aptamers are used for inhibition of biofilm formation, microbial toxins, and also as anti-bacterial agents. The use of aptamers for therapeutic purpose often encounters several roadblocks like stability, renal clearance, or filtration, elimination of excess unbound aptamers, biodistribution, or bioavailability at the desired tissue locations (Kovacevic et al., 2018; He et al., 2020).

Modifications in aptamers enable them to overcome the above mentioned hurdles and impart flexibility to execute various functions like: drug delivery, drug conjugation, imaging, biosensor, or aptamer tagging (especially useful for RNA aptamer) (Figure 3). In the current COVID-19 scenario, aptamers are being explored for the diagnosis as well as treatment options world-wide. In a recent article, aptamers have been reported against receptorbinding-domain (RBD) which could prevent binding of RBD with ACE2 receptor reflecting the potential of aptamers in SARS-CoV-2 (severe acute respiratory syndrome coronavirus 2) virus diagnosis and treatment (Song et al., 2020). Further, an aptamer that could bind to viral nucleoprotein, nucleolin, has been developed as a proof-of-concept for SARS-CoV-2 detection (Thomas, 2020). N protein of SARS-CoV-2 is essential for viral genome assembly; thus aptamer against $\mathrm{N}$ protein of SARS-CoV-2 might extend its use in diagnosis and treatment simultaneously (Song et al., 2020). This is a standout feature where an aptamer serves the purpose of both diagnosis and treatment.

\section{CHALLENGES IN TUBERCULOSIS DIAGNOSIS AND TREATMENT}

Despite extensive research activities, M.tb continued to kill millions of humans every year. Limitations of rapid and accurate diagnosis of tuberculosis, emergence of drug-resistance and HIV-TB co-infections are complicating TB treatment. For TB

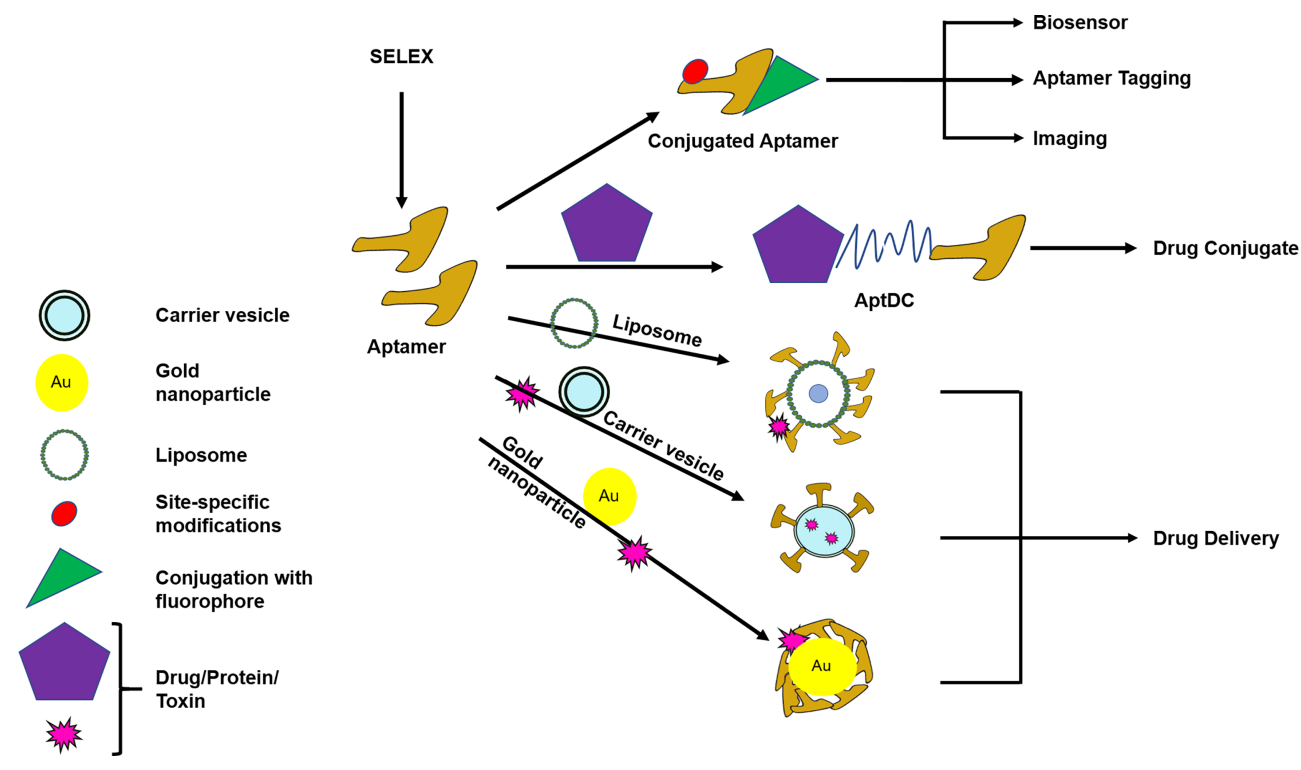

FIGURE 3 | Modification and conjugation of aptamers for the use of diagnostic and/or therapeutic purpose. Aptamers can be modified or conjugated with different substances to carry out various functions like drug delivery, drug conjugate, imaging, biosensor, or aptamer tagging. AptDC-Aptamer-Drug-conjugate. Routes of drug delivery are oral, intramuscular, parenteral, intravenous, rectal, topical, otherwise specified. Specialized drug delivery modes are liposomal, nanoparticle, carrier vesicle. Drug delivery optimization is needed to obtain the desired effect. 
diagnosis, smear microscopy is a less sensitive test. Culturing M.tb is the most accurate method to identify the pathogenic species, but it is time consuming and not suitable for point-of-care (POC) diagnosis. In PCR-based diagnosis, infection is confirmed by the presence of mycobacterial DNA or RNA sequence; however, the thermal cyclers are not readily available in resource-limited settings. On the other hand, rapid and less expensive POC, such as serological assays, is banned for testing the TB. WHO endorsed Gene-Xpert MTB/RIF, a specific, fast technique and revolutionary TB detection method based on PCR-DNA amplification, but it has certain limitations (WHO, 2019). Gene-Xpert fails to detect TB in children, smear-negative-TB infection. Also, for accuracy and fast performance, Gene-Xpert M.tb requires skilled manpower and sophisticated instrument setup. Tuberculin skin test (TST) and Interferon- $\gamma$-Release-Assay (IGRA) are immunological tests based on the principle of antigen-antibody reaction. Interferon- $\gamma$ is a pro-inflammatory cytokine, released during tuberculosis infection. IFN- $\gamma$ is measured by ELISA from TB patients' blood. These tests fail to differentiate between active TB, latent TB, or relapsed TB. Despite these advancements, the diagnosis of $M . t b$ infection still requires a rapid, accurate, and efficient diagnostic platform. It has been estimated that 0.5 million people fell ill with drug resistant $\mathrm{TB}$, and only one in three TB patients had access to treatment (WHO, 2019). There is a requirement of USD 10.1 billion for TB diagnosis, treatment, and care. Successful treatment of tuberculosis (TB) infection is one of the fierce challenges faced by physicians, which is mainly because of the unavailability of accurate information about M.tb species and its drug-resistant status leading to treatment failure. As a result, multi-drug-resistant (MDR) and extensively drug resistant (XDR) M.tb arise due to over and improper use of antibiotics during the treatment of TB (WHO, 2019). In the current COVID-19 crisis, it has been estimated that the death toll due to TB may rise up to $20 \%$ over the next five years (Hogan et al., 2020) and TB treatment may be side-lined and adversely affected.

\section{APTAMERS IN THE DIAGNOSTIC AND THERAPEUTIC APPLICATIONS OF M.TB}

Global efforts were taken to introduce aptamers for rapid diagnosis and therapeutic applications for tuberculosis (Zhu et al., 2012; Golichenari et al., 2018; Li et al., 2018). A gold nano-particle conjugated-CFP10-ESAT6 DNA aptamer was developed to detect M.tb, and it could differentiate between pathogenic and non-pathogenic M.tb bacteria (He et al., 2016). ESAT-6-based aptasensor ESAT6-P-MOF-rGO (metal organic framework graphene oxide-MOFGO) could detect ESAT-6 secretion in human serum samples (Li et al., 2018). Similarly, a sandwich ELISA can detect MPT64 aptamer (Figure 4) (Zhu et al., 2012). A pro-inflammatory cytokine, IFN- $\gamma$ is secreted in response to mycobacterial antigens. Recently, for detection of IFN- $\gamma$ release, a SPR based-dual-aptamer sensor has been designed. In this sensor, aptamer against IFN- $\gamma$ is coupled with streptavidin specific aptamer. Streptavidin aptamer performs dual function of "a reporter" and "an amplifier". Such dual DNA probe was able to detect low level of IFN- $\gamma$ in plasma isolated from healthy individuals because they have less IFN- $\gamma$ concentration (Min et al., 2008; Chang et al., 2012). Another aptamer, MTB36 also shows preferential binding with $M . t b$ over M. bovis BCG suggesting its ability to discriminate between close species (Mozioglu et al., 2016). PPK (polyphosphate kinase gene) regulates inorganic polyphosphate (polyP) function and aids in virulence. An aptamer G9 has been shown to inhibit PPK activity rendering inhibition of polyp-mediated metabolic process in
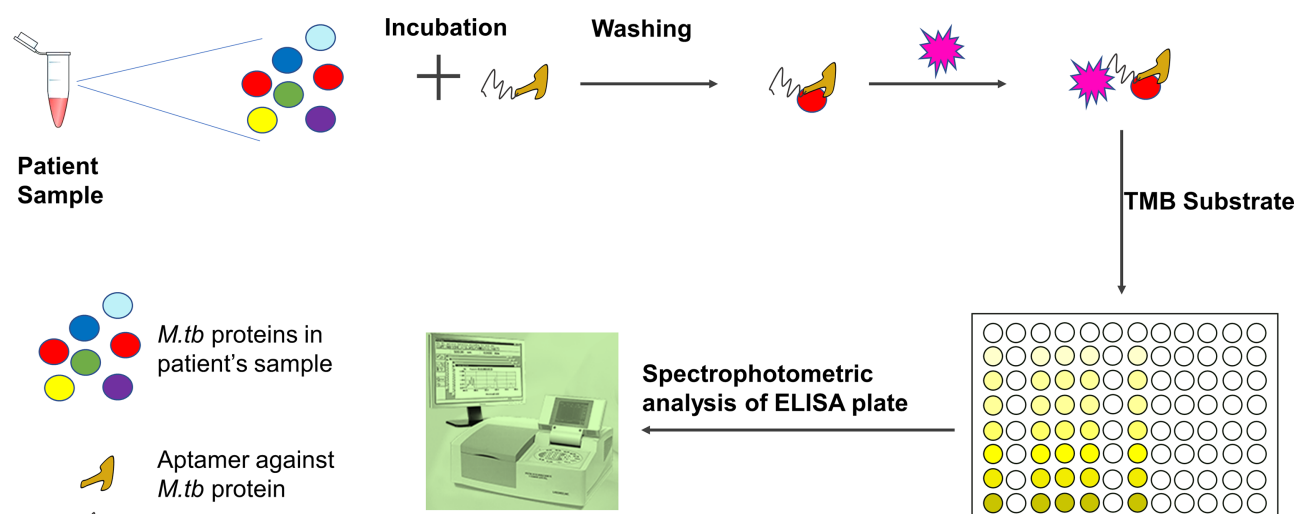

Spectrophotometric analysis of ELISA plate

Aptamer against
M.tb protein
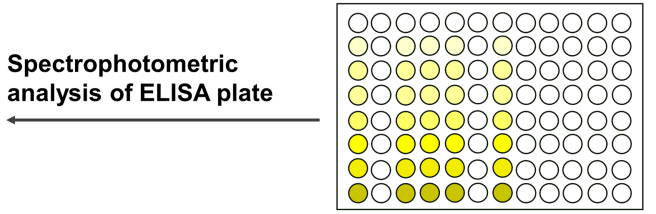

ELISA plate

FIGURE 4 | Detection of M.tb proteins using aptamer-based ELISA or ELONA (ELONA-enzyme-linked oligonucleotide assay). In an ELISA plate, the patient sample is incubated with biotinylated aptamer specific for M.tb protein. After washing, streptavidin-HRP is added and ELISA is developed using TMB substrate. The optical density is measured using a spectrophotometer. Patient sample could be blood, serum, sputum, or body fluid. Viscous fluid like sputum can be diluted and vortexed before incubation with aptamer. 
M.tb (Shum et al., 2011). Culture filtrate protein-10 (CFP-10) and early secreted antigenic target of $6 \mathrm{kDa}$ (ESAT-6) proteins are secreted during TB infection. Aptamer CSIR2.11 could detect CFP-10-ESAT-6 complex as well as CFP-10 alone from sputum sample of TB patients. The sensitivity and specificity of CSIR 2.11 were found to be 100 and $68.75 \%$ in sputum sample of TB patients (Rotherham et al., 2012). A DNA aptamer, H63SL2-M6 against HspX, a mycobacterial antigen highly expressed in TB patients, had been shown to detect HspX in sputum of TB infected individuals using aptamer-linked immobilized sorbent assay (Aptamer ALISA). The performance of ALISA was superior to conventional ELISA (Lavania et al., 2018). Further, an electrochemical sensor (ECS) device based on H63SL2-M6 aptamer was developed as POC diagnosis (Lavania et al., 2018). HupB (Rv2986c) is a promising drug target against TB. It is an essential histone-like protein of $M . t b$ which protects $M . t b$ DNA from damage and regulates iron homeostasis (Pandey et al., 2014). G-quadraplex forming DNA aptamers, HupB-4T and HupB-13T, were developed to block DNA-binding activity of HupB. HupB proteins are required for macrophage entry of M.tb. Inhibition of HupB function by HupB-4T and HupB-13T has been shown to arrest the bacterial entry into macrophages. Thus HupB-4T and HupB-13T could serve as inhibitors of HupB functions (Kalra et al., 2018). A proteomic-based SOMAscan was developed for $M . t b$ diagnosis, but it failed to identify noticeable difference between TB and non-TB patients' serum (Russell et al., 2017). Malate synthase (MS) enzyme of the glyoxylate pathway converts malate by using glyoxylate and acetyl-CoA. MS expresses in cell wall and promotes adhesion of bacteria. Another g-quadruplex DNA aptamer, MS10, binds to MS and inhibits its enzymatic activity (Dhiman et al., 2019). ESX3 secretion system of $M$.tb secretes EsxG protein. RNA aptamers against G43 and G78 bind to EsxG but not to EsxA, suggesting that aptamers can differentiate between closely related proteins and bind to their specific partners only (Ngubane et al., 2014). Whole-cell-SELEX identifies the receptors present on the target cell in their native confirmation. Hence, aptamers developed in this way perform better than aptamers developed using recombinantly purified target (Dwivedi et al., 2013; Aimaiti et al., 2015). Aptamers generated through such method could differentiate $M . t b \mathrm{H} 37 \mathrm{Rv}$ from non-tuberculous mycobacteria. An aptamer MA1 or combination of MA1/MA2 aptamers recognizes $M . t b \mathrm{H} 37 \mathrm{Rv}$ preferentially as compared to $M$. marianum (Aimaiti et al., 2015). M.tb Ag85 complex is secreted as protein complex of three proteins, A, B, and C and is important for cell wall biosynthesis. Ag85 complex is considered to be a potent biomarker for TB diagnosis. Cerebrospinal fluid of patients suffering from tuberculous meningitis also showed the presence of Mycobacterium antigen 85 complex (Ag85 complex) (Kashyap et al., 2005). A fluorescent aptasensor, ATTO647N-Apt22, is developed to detect Ag85 complex (Ansari et al., 2017). Entry of aptamers are relatively new in the field of TB drug discovery/or development. Hence, there is only a handful of examples where aptamers have been shown or developed for anti-mycobacterial function (Table 3). The $M . t b$ virulent proteins infect macrophages and weaken the immune system. Since macrophages are preferred niche for M.tb, aptamers preventing macrophage invasion can help in controlling M.tb infection (Chen et al., 2012; Kalra et al., 2018). NK2 aptamers inhibit invasion of $M . t b$ in macrophages, enhances IFN- $\gamma$ production, and increases survival of mice infected with $M . t b$ (Chen et al., 2012). The 6-kDa early secreted antigenic target (ESAT-6) and $10-\mathrm{kDa}$ culture filtrate protein (CFP-10) are secretory proteins of virulent M.tb. ssDNA aptamers (CE24 and CE15) can detect CFP-10 and ESAT-6 proteins respectively in serum samples from active pulmonary tuberculosis patients, extrapulmonary TB patients, and healthy individuals (Tang et al., 2014). Mannose-capped lipoarabinomannan (ManLam), a cell wall component of M.tb, is important for M.tb pathogenesis (Tang et al., 2016). ManLam inhibits antigen presentation function of dendritic cells. Aptamer T9 can detect ManLAM antigen in serum and sputum samples from active pulmonary tuberculosis (aPTB) patients, extrapulmonary TB (EPTB) patients, and healthy donors with $>85 \%$ specificity and sensitivity. The performance of $\mathrm{T} 9$ based enzyme-linked oligonucleotide assay (ELONA) was comparable with the standard T-SPOT.TB test.

TABLE 3 | Aptamers developed for diagnosis and therapeutic applications in tuberculosis.

\begin{tabular}{|c|c|c|c|c|c|}
\hline S. No. & Aptamer & Type & Organism & Target & Reference \\
\hline \multicolumn{6}{|c|}{ For Diagnosis } \\
\hline 1. & CE24 CE15 & DNA & M.tb $\mathrm{H}_{37} \mathrm{Rv}$ & CE protein & Tang et al., 2014 \\
\hline 2. & CSIR 2.11 & DNA & M.tb & CE protein & Rotherham et al., 2012 \\
\hline 3. & MPT64-A1 & DNA & M.tb & MPT64 & Zhu et al., 2012 \\
\hline 4. & G43 G78 & RNA & M.tb & EsxG protein & Ngubane et al., 2014 \\
\hline 5. & MA1 & DNA & M.tb & Whole-bacterium & Aimaiti et al., 2015 \\
\hline 6. & Aptamer 1 & DNA & M.tb & Whole-bacterium & Chen et al., 2007 \\
\hline 7. & Au-IDE/CFP10- ESAT6 & DNA & M.tb & Whole-bacterium & He et al., 2016 \\
\hline \multicolumn{6}{|c|}{ For therapeutic } \\
\hline 8. & NK2 & DNA & M.tb H37Rv & Whole-bacterium & Chen et al., 2007 \\
\hline 9. & ZXL1 & DNA & M.tb H37Rv & ManLAM & Pan et al., 2014 \\
\hline \multirow[t]{2}{*}{10.} & M. tb -Apt1 & DNA & M.tb & Acetohydroxyacid synthase & Baig et al., 2015 \\
\hline & M. tb -Apt6 & & & & \\
\hline 11. & $\mathrm{BM} 2$ & DNA & BCG & ManLAM & Sun et al., 2016 \\
\hline 12. & T9 & DNA & M.tb Beijing strains & ManLAM & Tang et al., 2016 \\
\hline 13. & CD44-TA-SMP & - & M.tb & CD44 receptor & Leonard et al., 2017 \\
\hline
\end{tabular}


T9-based ELONA (Figure 4) has been touted as improved diagnostic test with potential to detect inactive TB, smearnegative TB, EPTB, and TB with HIV but its inefficiency to differentiate between LTBI and active TB limits its application. Nonetheless, T9-based ELONA is fast and less expensive than TSPOT.TB test (Tang et al., 2016). An aptamer ZXL1 recognizes acyl and phosphate structures of ManLAM and binds to M.tbManLAM, not to BCG-ManLAM. ZXL1 suppresses CD11+ expression in dendritic cells and inhibits M.tb H37Rv infection in mice and rhesus monkeys. The ability to differentiate between M.tb-ManLam versus BCG-ManLam acknowledges the potential of ZXL1 as a future candidate for developing tuberculosis vaccine (Pan et al., 2014). Acetoacetate is an important intermediate molecule in essential amino acid synthesis. Acetohydroxy acid synthase (ASHS) has no known functional analogs in humans, which makes it a good drug candidate. ASHS converts pyruvate molecule to acetoacetate. ssDNA aptamers named as M.tb-Apt1 and M.tb-Apt6 inhibit ASHS activity and are able to kill MDR strain of M.tb (Baig et al., 2015). Aptamer BM2 increases the immunogenicity of BCG against virulent $M . t b, \mathrm{H} 37 \mathrm{Rv}$ infection in monkeys as well as in mice model (Sun et al., 2016). BM2 aptamer targets BCG-ManLAM-CD44 interaction and initiates M1 macrophage-mediated Th1 (T helper 1) T cell immune response (Sun et al., 2016). Thioaptamers (TA) are modified aptamer having thiophosphate ester bond (Somasunderam et al., 2010). CD44 is a conserved receptor present on macrophages. $M$. $t b$ binds to CD44 and enters inside the macrophages (Leemans et al., 2003). Conjugation of CD44-thioaptamers with SMP (discoidal silicon mesoporous microparticles) enhanced the internalization of aptamers and killed M.tb-infected macrophages in mice lung (Leonard et al., 2017).

\section{FUTURE DIRECTION FOR DEVELOPMENT OF APTAMERS FOR TB RESEARCH}

As shown by Chen et al., 2020, an aptamer which was generated for detecting $\mathrm{N}$ protein of SARS-CoV2, can also be used for the treatment as well. Such rationale can also be adopted while developing aptamers targeting $M . t b$ cell wall proteins, virulent factors, secretory proteins, or combination of above factors that could be a substitute of conventional diagnosis approaches. Aptamers generated against whole bacterium are regarded suitable for diagnostic purposes as they can recognize different epitopes present on M.tb and detect them in human fluid i.e. blood, serum, bronchoalveolar lavage (Chen et al., 2007; Zhu et al., 2012; Rotherham et al., 2012). Aptamers can also be designed against PE/PPE family proteins as they have shown to induce strong antibody responses in smear negative and extrapulmonary $\mathrm{TB}$ and also in individuals with latent tuberculosis (Mukherjee et al., 2007; Khan et al., 2008; Tundup et al., 2008; Abraham et al., 2014; Khan et al., 2016; Abraham et al., 2018). Since approximately $10 \%$ of $M . t b$ genome codes for $\mathrm{PE} / \mathrm{PPE}$ proteins, it is of interest to explore the possibility of using the PE/PPE based aptamers for TB and latent TB diagnosis. Various studies have shown that $\mathrm{PE} / \mathrm{PPE}$ proteins can be used as potential markers for serodiagnosis of active TB as well as latent TB infection. Aptamers for PPE proteins such PPE17 (Abraham et al., 2016), PPE2 (Abraham et al., 2014), PPE68 (Xu et al., 2012), PPE42 (Chakhaiyar et al., 2004; Ireton et al., 2010), PPE57 (Zhang et al., 2007), and PPE41 (Choudhary et al., 2003) may be tested for diagnosis of TB. In addition, aptamers for PE proteins such as PE25 (Tundup et al., 2008), PE11 (Narayana et al., 2007) and PE35 (Mukherjee et al., 2007) could be explored for diagnostic assessment. Anti-M.tb aptamers may also be required to differentiate different strains of $M . t b$ that may help in understanding the transmission dynamics of TB in different geographical locations/endemic areas of TB. It will be worth inventing aptamers that can identify drug resistant $M$. $t b$ isolates for prescribing appropriate anti-TB regimen. $M . t b$ resides inside macrophages and incapacitates the human immune system. Thus, aptamers can be designed to block, inhibit, or prevent the functions of virulent factors of mycobacteria and may be exploited as therapeutics. For example, our recent studies (Nair et al., 2009; Nair et al., 2011), indicated an important role of the LRR (leucine rich repeat) 11-15 domains of toll like receptor (TLR) 2 in the induction of non-protective IL-10/Th2 response by PPE18 protein of M.tb (Nair et al., 2009; Nair et al., 2011); thus aptamers can be designed to block this interaction to specifically increase the protective Th1-type immune response against M.tb. Also our recent study indicates that the PPE2 protein of M.tb interacts with p67phox in macrophages and inhibits reactive oxygen species (Srivastava et al., 2019). Aptamers to block this interaction may be useful to increase the innate host defense during M.tb infection. Similarly, another protein, PE11, is found to be responsible for cell wall architecture of M.tb, contributing to M.tb virulence (Singh et al., 2016; Rastogi et al., 2017) and can be the target of aptamer research. Also we report that ESAT- 6 protein interacts with $\beta_{2}$-microglobulin of host inhibiting class I-mediated antigen presentation and CD8+ T cell function (Sreejit et al., 2014). It is probably important to design the aptamer to specifically block this interaction to improve CD8+ T cell function which is shown to be poorer and/or delayed during M.tb infection (Koul et al., 2004).

\section{CONCLUDING REMARKS}

Our current knowledge of cellular and molecular interactions between mycobacteria and host immune responses is poor, and the complex pathobiology of tuberculosis presents a significant challenge in vaccine development. Recent advancement in aptamer technology has come up with novel and imaginative ways to develop therapeutic and diagnostic aptamers against important molecular targets of M.tb. In the management of tuberculosis, early and accurate diagnosis is the key. Delayed diagnosis and poor treatment lead to the development of drug resistance. Hence, aptamers which can detect early infection stages or detect drug-resistant $M . t b$ strain would be effective in the management of TB. In DOTS (directly observed treatment, shortcourse) therapy for tuberculosis management, a combination of antibiotics is given for a long period of time. M.tb develops drug 
resistance, and thus the currently available drugs generally fail to clear the infection. Most antibiotics are generated against enzymes important for cell wall formation, biofilm synthesis, or DNA replication, and protein synthesis pathway, or they target they metabolic pathway of M.tb (Davydova et al., 2016). Aptamers do not target enzymatic pathway directly. They are designed to recognize their target, bind to and inhibit the functions. In this way, aptamers are believed to overcome the problem of generation of resistant mycobacteria. Aptamers are sensitive to nucleasemediated degradation. Being smaller in size, localization of aptamers to its site-of-action is challenging. Additionally, aptamers are rapidly cleared from the body due to high renal filtration. There is a new class of aptamers known as SOMAmer (Slow-Off rate-Modified-Aptamer) that are modified nucleotide aptamers having side-chains to facilitate strong hydrophobic interaction with their target. SOMAmer stays in circulation for longer duration. Though aptamers offer a bundle of advantages, they have some shortcomings which need to be overcome before aptamers can be fully exploited true to their potential. In TB diagnosis platform, even highly advanced technique suffers due to extremely low concentration of M.tb antigens in serum, blood, urine, etc. Though there have been significant improvement in the diagnosis and treatment of tuberculosis, still we are unable to address the basic question of preventing the emergence of drug-resistant $M . t b$ or minimizing the side effects of antibiotics or development of an effective anti-TB vaccine. Aptamers are unique, less expensive, and simple oligonucleotide molecules. They are flexible and they can be conjugated with a variety of agents like siRNA, drugs, and nanoparticle molecules (Jiang et al., 2015;

\section{REFERENCES}

Abraham P. R., Devalraju K. P., Jha V., Valluri V. L., and Mukhopadhyay S. (2018). PPE17 (Rv1168c) Protein of Mycobacterium Tuberculosis Detects Individuals With Latent TB Infection. PloS One 13, e0207787. doi: 10.1371/ journal.pone.0207787

Abraham P. R., Latha G. S., Valluri V. L., and Mukhopadhyay S. (2014). Mycobacterium Tuberculosis PPE Protein Rv0256c Induces Strong B Cell Response in Tuberculosis Patients. Infect. Genet. Evol. 22, 244-249. doi: 10.1016/j.meegid.2013.06.023

Abraham P. R., Udgata A., Latha G. S., and Mukhopadhyay S. (2016). The Mycobacterium Tuberculosis PPE Protein Rv1168c Induces Stronger B Cell Response Than Rv0256c in Active TB Patients. Infect. Genet. Evol. 40, 339-345. doi: 10.1016/j.meegid.2015.09.005

Aimaiti R., Qin L., Cao T., Yang H., Wang J., Lu J., et al. (2015). Identification and Application of ssDNA Aptamers Against H37Rv in the Detection of Mycobacterium Tuberculosis. Appl. Microbiol. Biotechnol. 99, 9073-9083. doi: 10.1007/s00253-015-6815-7

Ansari N., Ghazvini K., Ramezani M., Shahdordizadeh M., Yazdian-Robati R., Abnous K., et al. (2017). Selection of DNA Aptamers Against Mycobacterium Tuberculosis Ag85A, and its Application in a Graphene Oxide-Based Fluorometric Assay. Mikrochimica Acta 185, 21. doi: 10.1007/s00604-017-2550-3

Baig I. A., Moon J. Y., Lee S. C., Ryoo S. W., and Yoon M. Y. (2015). Development of ssDNA Aptamers as Potent Inhibitors of Mycobacterium Tuberculosis Acetohydroxyacid Synthase. Biochim. Biophys. Acta 1854, 1338-1350. doi: 10.1016/j.bbapap.2015.05.003

Basler C. F., Mikulasova A., Martinez-Sobrido L., Paragas J., Mühlberger E., Bray M., et al. (2003). The Ebola Virus VP35 Protein Inhibits Activation of Interferon Regulatory Factor 3. J. Virol. 77, 7945-7956. doi: 10.1128/ jvi.77.14.7945-7956.2003
Davydova et al., 2016). Advancement in aptamer technology which will certainly lead to selectively target virulent proteins of $M . t b$ would pave the way for new and improved vaccine and drug development. Aptamer technology is in its nascent phase; however measured interventions in aptamer have the potential to replace conventional way of TB management in future.

\section{AUTHOR CONTRIBUTORS}

SS-Preparation of first draft and revision. PRA—Conceptualization and review. SM-Conceptualization, review and finalization of the manuscript. All authors contributed to the article and approved the submitted version.

\section{FUNDING}

This work was supported by grants from the Department of Biotechnology (DBT), Government of India (BT/PR20669/ MED/29/1072/2016), Science and Engineering Research Board (SERB), Department of Science and Technology (DST), Government of India (DST/SERB/CRG/2019/000239), TATA Innovation Fellowship, DBT (BT/HRD/35/01/03/2018), Council of Scientific and Industrial Research (CSIR), Govt. of India (27(0364)/20/EMR-II), and a core grant from the Centre for DNA Fingerprinting and Diagnostics by the Department of Biotechnology (DBT) to SM.

Bianchini M., Radrizzani M., Brocardo M. G., Reyes G. B., Gonzalez S. C., SantaColoma T. A., et al. (2001). Specific Oligobodies Against ERK-2 That Recognize Both the Native and the Denatured State of the Protein. J. Immunol. Methods 252, 191-197. doi: 10.1016/s0022-1759(01)00350-7

Bruno J. G., Richarte A. M., Phillips T., Savage A. A., Sivils J. C., Greis A., et al. (2014). Development of a Fluorescent Enzyme-Linked DNA Aptamer-Magnetic Bead Sandwich Assay and Portable Fluorometer for Sensitive and Rapid Leishmania Detection in Sandflies. J. Fluoresc 24, 267-277. doi: 10.1007/s10895-013-1315-6

Burke D. H., and Willis J. H. (1998). Recombination, RNA Evolution, and Bifunctional RNA Molecules Isolated Through Chimeric SELEX. RNA 4, 1165-1175. doi: 10.1017/s1355838298980542

Cárdenas W. B., Loo Y. M., Gale M., Hartman A. L., Kimberlin C. R., MartínezSobrido L., et al. (2006). Ebola Virus VP35 Protein Binds Double-Stranded RNA and Inhibits Alpha/Beta Interferon Production Induced by RIG-I Signaling. J. Virol. 80, 5168-5178. doi: 10.1128/JVI.02199-05

Chakhaiyar P., Nagalakshmi Y., Aruna B., Murthy K. J., Katoch V. M., and Hasnain S. E. (2004). Regions of High Antigenicity Within the Hypothetical PPE Major Polymorphic Tandem Repeat Open-Reading Frame, Rv2608, Show a Differential Humoral Response and a Low T Cell Response in Various Categories of Patients With Tuberculosis. J. Infect. Dis. 190, 1237-1244. doi: 10.1086/423938

Chang C. C., Lin S., Lee C. H., Chuang T. L., Hsueh P. R., Lai H. C., et al. (2012). Amplified Surface Plasmon Resonance Immunosensor for Interferon-GammaBased on a Streptavidin-Incorporated Aptamer. Biosens Bioelectron 37, 68-74. doi: 10.1016/j.bios.2012.04.038

Cheng C., Chen Y. H., Lennox K. A., Behlke M. A., and Davidson B. L. (2013). In Vivo SELEX for Identification of Brain-Penetrating Aptamers. Mol. Ther. Nucleic Acids 2, e67. doi: 10.1038/mtna.2012.59

Chen Z., Wu Q., Chen J., Ni X., and Dai J. (2020). A DNA Aptamer Based Method for Detection of SARS-CoV-2 Nucleocapsid Protein. Virol. Sin. 35, 351-354. doi: $10.1007 / \mathrm{s} 12250-020-00236-\mathrm{Z}$ 
Chen F., Zhang X., Zhou J., Liu S., and Liu J. (2012). Aptamer Inhibits Mycobacterium Tuberculosis (H37Rv) Invasion of Macrophage. Mol. Biol. Rep. 39, 2157-2162. doi: 10.1007/s11033-011-0963-3

Chen F., Zhou J., Luo F., Mohammed A. B., and Zhang X. L. (2007). Aptamer From Whole-Bacterium SELEX as New Therapeutic Reagent Against Virulent Mycobacterium Tuberculosis. Biochem. Biophys. Res. Commun. 357, 743-748. doi: 10.1016/j.bbrc.2007.04.007

Choudhary R. K., Mukhopadhyay S., Chakhaiyar P., Sharma N., Murthy K. J., Katoch V. M., et al. (2003). PPE Antigen Rv2430c of Mycobacterium Tuberculosis Induces a Strong B-Cell Response. Infect. Immun. 71, 63386343. doi: 10.1128/iai.71.11.6338-6343.2003

Cho S. J., Woo H. M., Kim K. S., Oh J. W., and Jeong Y. J. (2011). Novel System for Detecting SARS Coronavirus Nucleocapsid Protein Using an ssDNA Aptamer. J. Biosci. Bioeng 112, 535-540. doi: 10.1016/j.jbiosc.2011.08.014

Cho M., Xiao Y., Nie J., Stewart R., Csordas A. T., Oh S. S., et al. (2010). Quantitative Selection of DNA Aptamers Through Microfluidic Selection and High-Throughput Sequencing. Proc. Natl. Acad. Sci. U. S. A. 107, 1537315378. doi: 10.1073/pnas.1315866110

Coulter L. R., Landree M. A., and Cooper T. A. (1997). Identificationof a New Class of Exonic Splicing Enhancers by In Vivo Selection. Mol. Cell. Biol. 17, 2143-2150. doi: 10.1128/mcb.17.4.2143

Dassie J. P., Liu X. Y., Thomas G. S., Whitaker R. M., Thiel K. W., Stockdale K. R., et al. (2009). Systemic Administration of Optimized Aptamer-siRNA Chimeras Promotes Regression of PSMA-Expressing Tumors. Nat. Biotechnol. 27, 839849. doi: $10.1038 /$ nbt. 1560

Davydova A., Vorobjeva M., Pyshnyi D., Altman S., Vlassov V., and Venyaminova A. (2016). Aptamers Against Pathogenic Microorganisms. Crit. Rev. Microbiol. 42, 847-865. doi: 10.3109/1040841X.2015.1070115

Dhiman A., Kumar C., Mishra S. K., Sikri K., Datta I., Sharma P., et al. (2019). Theranostic Application of a Novel G-quadruplex-forming Dna Aptamer Targeting Malate Synthase of Mycobacterium Tuberculosis. Mol. Ther. Nucleic Acids 18, 661-672. doi: 10.1016/j.omtn.2019.09.026

Duo J., Chiriac C., Huang R. Y., Mehl J., Chen G., Tymiak A., et al. (2018). Slow Off-Rate Modified Aptamer (Somamer) as a Novel Reagent in Immunoassay Development for Accurate Soluble Glypican-3 Quantification in Clinical Samples. Anal. Chem. 90, 5162-5170. doi: 10.1021/acs.analchem.7b05277

Dwivedi H. P., Smiley R. D., and Jaykus L. A. (2013). Selection of DNA Aptamers for Capture and Detection of Salmonella Typhimurium Using a Whole Cell SELEX Approach in Conjunction With Cell Sorting. Appl. Microbiol. Biotechnol. 97, 3677-3686. doi: 10.1007/s00253-013-4766-4

Ellington A. D., and Szostak J. W. (1992). In Vitro Selection of Single-Stranded DNA Molecules That Fold Into Specific Ligand-Binding Structures. Nature 355, 850-852. doi: 10.1038/355850a0

Esposito C. L., Cerchia L., Catuogno S., De Vita G., Dassie J. P., Santamaria G., et al. (2014). Multifunctional aptamer-miRNA Conjugates for Targeted Cancer Therapy. Mol. Ther. 22, 1151-1163. doi: 10.1038/mt.2014.5

Gawande B. N., Rohloff J. C., Carter J. D., von Carlowitz I., Zhang C., Schneider D. J., et al. (2017). Selection of DNA Aptamers With Two Modified Bases. Proc. Natl. Acad. Sci. U. S. A. 114, 2898-2903, 114. doi: 10.1073/pnas.1615475114

Girvan A. C., Teng Y., Casson L. K., Thomas S. D., Jüliger S., Ball M. W., et al. (2006). AGRO100 Inhibits Activation of Nuclear Factor- $\mathrm{KB}$ (NF- $\mathrm{\kappa B}$ ) by Forming a Complex With NF-кB Essential Modulator (NEMO) and Nucleolin. Mol. Cancer Ther. 5, 1790-1799. doi: 10.1158/1535-7163.MCT-05-0361

Golden M. C., Collins B. D., Willis M. C., and Koch T. H. (2000). Diagnostic Potential of PhotoSELEX-evolved ssDNA Aptamers. J. Biotechnol. 81, 167178. doi: 10.1016/s0168-1656(00)00290-x

Golichenari B., Nosrati R., Farokhi-Fard A., Abnous K., Vaziri F., and Behravan J. (2018). Nano-Biosensing Approaches on Tuberculosis: Defy of Aptamers. Biosens Bioelectron 117, 319-331. doi: 10.1016/j.bios.2018.06.025

He F., Wen N., Xiao D., Yan J., Xiong H., Cai S., et al. (2020). Aptamer-Based Targeted Drug Delivery Systems: Current Potential and Challenges. Curr. Med. Chem. 27, 2189-2219. doi: 10.2174/0929867325666181008142831

He F., Xiong Y., Liu J., Tong F., and Yan D. (2016). Construction of Au-IDE/ CFP10-ESAT6 Aptamer/DNA-Aunps MSPQC for Rapid Detection of Mycobacterium Tuberculosis. Biosens Bioelectron 77, 799-804. doi: 10.1016/ j.bios.2015.10.054

Hogan A. B., Jewell B., Sherrard-Smith E., Vesga J., Watson O. J., Whittaker C., et al. (2020) Report 19: The Potential Impact of the COVID-19 Epidemic on
HIV, TB and Malaria in Low and Middle-Income Countries (London: United Kingdom: Imperial College London). Available at: https://www.imperial.ac.uk/ mrc-globalinfectious-disease-analysis/covid-19/report-19-hiv- tb-malaria/ (Accessed June 22, 2020).

Homann M., and Goringer H. U. (1999). Combinatorial Selection of High Affinity RNA Ligands to Live African Trypanosomes. Nucleic Acids Res. 27, 2006-2014. doi: 10.1093/nar/27.9.2006

Hong K. L., and Sooter L. J. (2015). Single-stranded DNA Aptamers Against Pathogens and Toxins: Identification and Biosensing Applications. Biomed. Res. Int. 2015:419318. doi: 10.1155/2015/419318

Hoon S., Zhou B., Janda K. D., Brenner S., and Scolnick J. (2011). Aptamer Selection by High-Throughput Sequencing and Informatic Analysis. Biotechniques 51, 413-416. doi: 10.2144/000113786

Ireson C. R., and Kelland L. R. (2006). Discovery and Development of Anticancer Aptamers. Mol. Cancer Ther. 5, 2957-2962. doi: 10.1158/15357163.MCT-06-0172

Ireton G. C., Greenwald R., Liang H., Esfandiari J., Lyashchenko K. P., and Reed S. G. (2010). Identification of Mycobacterium Tuberculosis Antigens of High Serodiagnostic Value. Clin. Vaccine Immunol. 17, 1539-1547. doi: 10.1128/ CVI.00198-10

Jenison R. D. (1994). High-Resolution Molecular Discrimination by RNA. Science 263, 1425-1429. doi: 10.1126/science.7510417

Jiang F., Liu B., Lu J., Li F., Li D., Liang C., et al. (2015). Progress and Challenges in Developing aptamer-Functionalized Targeted Drug Delivery Systems. Int. J. Mol. Sci. 16, 23784-23822. doi: 10.3390/ijms161023784

Kalra P., Mishra S. K., Kaur S., Kumar A., Prasad H. K., Sharma T. K., et al. (2018). G-Quadruplex-Forming DNA Aptamers Inhibit the DNA-binding Function of HupB and Mycobacterium Tuberculosis Entry Into Host Cells. Mol. Ther. Nucleic Acids 13, 99-109. doi: 10.1016/j.omtn.2018.08.011

Kashyap R. S., Dobos K. M., Belisle J. T., Purohit H. J., Chandak N. H., Taori G. M., et al. (2005). Demonstration of Components of Antigen 85 Complex in Cerebrospinal Fluid of Tuberculous Meningitis Patients. Clin. Diagn Lab. Immunol. 12, 752-758. doi: 10.1128/CDLI.12.6.752-758.2005

Kawakami J., Imanaka H., Yokota Y., and Sugimoto N. (2000). In Vitro Selection of Aptamers That Act With Zn2+. J. Inorg. Biochem. 82, 197-206. doi: 10.1016/ s0162-0134(00)00158-6

Khan N., Alam K., Nair S., Valluri V. L., Murthy K. J., and Mukhopadhyay S. (2008). Association of Strong Immune Responses to PPE Protein Rv1168c With Active Tuberculosis. Clin. Vaccine Immunol. 15, 974-980. doi: 10.1128/ CVI.00485-07

Khan T. A., Mazhar H., Saleha S., Tipu H. N., Muhammad N., and Abbas M. N. (2016). Interferon-gamma Improves Macrophages Function Against $M$. Tuberculosis in Multidrug-Resistant Tuberculosis Patients. Chemother. Res. Pract. 2016, 7295390. doi: 10.1155/2016/7295390

Koul A., Herget T., Klebl B., and Ullrich A. (2004). Interplay Between Mycobacteria and Host Signaling Pathways. Nat. Rev. Microbiol. 2, 189-202. doi: $10.1038 /$ nrmicro840

Kovacevic K. D., Gilbert J. C., and Jilma B. (2018). Pharmacokinetics, Pharmacodynamics and Safety of Aptamers. Adv. Drug Deliv Rev. 134, 3650. doi: 10.1016/j.addr.2018.10.008

Lahousse M., Park H. C., Lee S. C., Ha N. R., Jung I. P., Schlesinger S. R., et al. (2018). Inhibition of Anthrax Lethal Factor by ssDNA Aptamers. Arch. Biochem. Biophys. 646, 16-23. doi: 10.1016/j.abb.2018.03.028

Lavania S., Das R., Dhiman A., Myneedu V. P., Verma A., Singh N., et al. (2018). Aptamer-Based TB Antigen Tests for the Rapid Diagnosis of Pulmonary Tuberculosis: Potential Utility in Screening for Tuberculosis. ACS Infect. Dis. 4, 1718-1726. doi: 10.1021/acsinfecdis.8b00201

Leemans J. C., Florquin S., Heikens M., Pals S. T., van der Neut R., and van der Poll T. (2003). CD44 is a Macrophage Binding Site for Mycobacterium Tuberculosis That Mediates Macrophage Recruitment and Protective Immunity Against Tuberculosis. J. Clin. Invest 111, 681-689. doi: 10.1021/acsinfecdis.8b00201

Leonard F., Ha N. P., Sule P., Alexander J. F., Volk D. E., Lokesh G. L. R., et al. (2017). Thioaptamer Targeted Discoidal Microparticles Increase SelfImmunity and Reduce Mycobacterium Tuberculosis Burden in Mice. J. Control Release 266, 238-247. doi: 10.1016/j.jconrel.2017.09.038

Li K., Deng J., Jin H., Yang X., Fan X., and Li L. (2017). Chemical Modification Improves the Stability of the DNA Aptamer GBI-10 and its Affinity Towards Tenascin-C. Org. Biomol. Chem. 15, 1174-1182. doi: 10.1039/c6ob02577c 
Li L., Li Q., Liao Z., Sun Y., Cheng Q., Song Y., et al. (2018). Magnetism-Resolved Separation and Fluorescence Quantification for Near-Simultaneous Detection of Multiple Pathogens. Anal. Chem. 90, 9621-9628. doi: 10.1021/acs/ analchem. $8 \mathrm{~b} 02572$

Li L., Yuan Y., Chen Y., Zhang P., Bai Y., and Bai L. (2018). Aptamer Based Voltammetric Biosensor for Mycobacterium Tuberculosis Antigen ESAT-6 Using a Nanohybrid Material Composed of Reduced Graphene Oxide and a Metal-Organic Framework. Mikrochim Acta 185, 379. doi: 10.1007/s00604018-2884-5

Maier K. E., and Levy M. K. (2016). From Selection Hits to Clinical Leads: Progress in Aptamer Discovery. Mol. Ther. Methods Clin. Dev. 5, 16014. doi: 10.1038/ $\mathrm{mtm} .2016 .14$

Maimaitiyiming Y., Hong F., Yang C., and Naranmandura H. (2019). Novel Insights Into the Role of Aptamers in the Fight Against Cancer. J. Cancer Res. Clin. Oncol. 145, 797-810. doi: 10.1007/s00432-019-02882-7

Mendonsa S. D., and Bowser M. T. (2004). In Vitro Evolution of Functional DNA Using Capillary Electrophoresis. J. Am. Chem. Soc 126, 20-21. doi: 10.1021/ ja037832s

Mi J., Liu Y., Rabbani Z. N., Yang Z., Urban J. H., Sullenger B. A., et al. (2010). In Vivo Selection of Tumor-Targeting RNA Motifs. Nat. Chem. Biol. 6, 22-24. doi: 10.1038/nchembio.277

Min K., Cho M., Han S. Y., Shim Y. B., Ku J., and Ban C. (2008). A Simple and Direct Electrochemical Detection of Interferon- $\gamma$ Using its RNA and DNA Aptamers. Biosens Bioelectron 23, 1819-1824. doi: 10.1016/j.bios. 2008.02.021

Mongelard F., and Bouvet P. (2010). As-1411, a Guanosine-Rich Oligonucleotide Aptamer Targeting Nucleolin for the Potential Treatment of Cancer, Including Acute Myeloid Leukemia. Curr. Opin. Mol. Ther; 12, 107-114.

Mosing R. K., and Bowser M. T. (2009). Isolating Aptamers Using Capillary electrophoresis-SELEX (Ce-Selex). Methods Mol. Biol. 535, 33-43. doi: 10.1007/978-1-59745-557-2_3

Mozioglu E., Gokmen O., Tamerler C., Kocagoz Z. T., and Akgoz M. (2016). Selection of Nucleic Acid Aptamers Specific for Mycobacterium Tuberculosis. Appl. Biochem. Biotechnol. 178, 849-864. doi: 10.1007/s12010-015-1913-7

Mukherjee P., Dutta M., Datta P., Dasgupta A., Pradhan R., Pradhan M., et al. (2007). The RD1- Encoded Antigen Rv3872 of Mycobacterium Tuberculosis as a Potential Candidate for Serodiagnosis of Tuberculosis. Clin. Microbiol. Infect. 13, 146-152. doi: 10.1111/j.1469-0691.2006.01660.x

Nagarkatti R., Bist V., Sun S., Fortes de Araujo F., Nakhasi H. L., and Debrabant A. (2012). Development of an Aptamer-Based Concentration Method for the Detection of Trypanosoma Cruzi in Blood. PloS One 7, e43533. doi: 10.1371/ journal.pone. 0043533

Nair S., Pandey A. D., and Mukhopadhyay S. (2011). The PPE18 Protein of Mycobacterium Tuberculosis Inhibits NF- $\mathrm{kb} /$ Rel-Mediated Proinflammatory Cytokine Production by Upregulating and Phosphorylating Suppressor of Cytokine Signaling 3 Protein. J. Immunol. 186, 5413-5424. doi: 10.4049/ jimmunol.1000773

Nair S., Ramaswamy P. A., Ghosh S., Joshi D. C., Pathak N., Siddiqui I., et al. (2009). The PPE18 of Mycobacterium Tuberculosis Interacts With TLR2 and Activates IL-10 Induction in Macrophage. J. Immunol. 183, 6269-6281. doi: 10.4049/jimmunol.0901367

Narayana Y., Joshi B., Katoch V. M., Mishra K. C., and Balaji K. N. (2007). Differential B-cell Responses are Induced by Mycobacterium Tuberculosis PE Antigens Rv1169c, Rv0978c, and Rv1818c. Clin. Vaccine Immunol. 14, 13341341. doi: 10.1128/CVI.00181-07

Ng E. W. M., Shima D. T., Calias P., Cunningham E. T., Guyer D. R., and Adamis A. P. (2006). Pegaptanib, a Targeted anti-VEGF Aptamer for Ocular Vascular Disease. Nat. Rev. Drug Discovery 5, 123-132. doi: 10.1038/nrd1955

Ngubane N. A., Gresh L., Pym A., Rubin E. J., and Khati M. (2014). Selection of RNA Aptamers Against the M. Tuberculosis EsxG Protein Using Surface Plasmon Resonance-Based SELEX. Biochem. Biophys. Res. Commun. 449, 114-119. doi: 10.1016/j.bbrc.2014.04.163

Nimjee S. M., White R. R., Becker R. C., and Sullenger B. A. (2017). Aptamers as Therapeutics. Annu. Rev. Pharmacol. Toxicol. 57, 61-79. doi: 10.1146/annurevpharmtox-010716-104558

Nitsche A., Kurth A., Dunkhorst A., Pänke O., Sielaff H., Junge W., et al. (2007). One-Step Selection of Vaccinia Virus-Binding DNA Aptamers by Monolex. BMC Biotechnol. 7, 48. doi: 10.1186/1472-6750-7-48
Ochsner U. A., Green L. S., Gold L., and Janjic N. (2014). Systematic Selection of Modified Aptamer Pairs for Diagnostic Sandwich Assays. Biotechniques 56, 125-133. doi: 10.2144/000114134

Ohuchi S. P., Ohtsu T., and Nakamura Y. (2006). Selection of RNA Aptamers Against Recombinant Transforming Growth Factor- $\beta$ Type III Receptor Displayed on Cell Surface. Biochimie 88, 897-904. doi: 10.1016/ j.biochi.2006.02.004

Ouellet E., Foley J. H., Conway E. M., and Haynes C. (2015). Hi-Fi Selex: A HighFidelity Digital-PCR Based Therapeutic Aptamer Discovery Platform. Biotechnol. Bioeng 112, 1506-1522. doi: 10.1002/bit.25581

Pandey S. D., Choudhury M., Yousuf S., Wheeler P. R., Gordon S. V., Ranjan A., et al. (2014). Iron- Regulated Protein HupB of Mycobacterium Tuberculosis Positively Regulates Siderophore Biosynthesis and is Essential for Growth in Macrophages. J. Bacteriol. 196, 1853-1865. doi: 10.1128/JB.01483-13

Pan Q., Wang Q., Sun X., Xia X., Wu S., Luo F., et al. (2014). Aptamer Against Mannose-Capped Lipoarabinomannan Inhibits Virulent Mycobacterium Tuberculosis Infection in Mice and Rhesus Monkeys. Mol. Ther. 22, 940951. doi: $10.1038 / \mathrm{mt} .2014 .31$

Peng L., Stephens B. J., Bonin K., Cubicciotti R., and Guthold M. (2007). A Combined Atomic Force/Fluorescence Microscopy Technique to Select Aptamers in a Single Cycle From a Small Pool of Random Oligonucleotides. Microsc Res. Tech 70, 372-381. doi: 10.1002/jemt.20421

Rastogi S., Singh A. K., Pant G., Mitra K., Sashidhara K. V., and Krishnan M. Y. (2017). Down-regulation of PE11, a Cell Wall Associated Esterase, Enhances the Biofilm Growth of Mycobacterium Tuberculosis and Reduces Cell Wall Virulence Lipid Levels. Microbiology 163, 52-61. doi: 10.1099/mic.0.000417

Rotherham L. S., Maserumule C., Dheda K., Theron J., and Khati M. (2012) Selection and Application of ssDNA Aptamers to Detect Active TB From Sputum Samples. PloS One 7, e46862. doi: 10.1371/journal.pone.0046862

Russell T. M., Green L. S., Rice T., Kruh-Garcia N. A., Dobos K., De Groote M. A., et al. (2017). Potential of High-Affinity Slow Off-Rate Modified Aptamer Reagents for Mycobacterium Tuberculosis Proteins as Tools for Infection Models and Diagnostic Applications. J. Clin. Microbiol. 55, 3072-3088. doi: 10.1128/JCM.00469-17

Santulli-Marotto S., Nair S. K., Rusconi C., Sullenger B., and Gilboa E. (2003). Multivalent RNA Aptamers That Inhibit CTLA-4 and Enhance Tumor Immunity. Cancer Res. 63, 7483-7489.

Shum K. T., Lui E. L., Wong S. C., Yeung P., Sam L., Wang Y., et al. (2011). Aptamer-Mediated Inhibition of Mycobacterium Tuberculosis Polyphosphate Kinase 2. Biochemistry 50, 3261-3271. doi: 10.1021/bi2001455

Singer B. S., Shtatland T., Brown D., and Gold L. (1997). Libraries for Genomic SELEX. Nucleic Acids Res. 25, 781-786. doi: 10.1093/nar/25.4.781

Singh N. K., Jain P., Das S., and Goswami P. (2019). Dye Coupled AptamerCaptured Enzyme Catalyzed Reaction for Detection of Pan Malaria and P. Falciparum Species in Laboratory Settings and Instrument-Free Paper-Based Platform. Anal. Chem. 91, 4213-4221. doi: 10.1021/acs.analchem.9b00670

Singh P., Rao R. N., Reddy J. R., Prasad R. B., Kotturu S. K., Ghosh S., et al. (2016). PE11, a PE/PPE Family Protein of Mycobacterium Tuberculosis is Involved in Cell Wall Remodeling and Virulence. Sci. Rep. 6, 21624. doi: $10.1038 /$ srep 21624

Smith C. I. E., and Zain R. (2019). Therapeutic Oligonucleotides: State of the Art. Annu. Rev. Pharmacol. Toxicol. 59, 605-630. doi: 10.1146/annurev-pharmtox010818-021050

Sola M., Menon A. P., Moreno B., Meraviglia-Crivelli D., Soldevilla M. M., CartónGarcía F., et al. (2020). Aptamers Against Live Targets: Is In Vivo SELEX Finally Coming to the Edge? Mol. Ther. Nucleic Acids 21, 192-204. doi: 10.1016/j.omtn.2020.05.025

Somasunderam A., Ferguson M. R., Rojo D. R., Thiviyanathan V., Li X., O’Brien W. A., et al. (2005). Combinatorial Selection, Inhibition, and Antiviral Activity of DNA Thioaptamers Targeting the RNaseH Domain of HIV-1 Reverse Transcriptase. Biochemistry 44, 10388-10395. doi: 10.1021/bi0507074

Somasunderam A., Thiviyanathan V., Tanaka T., Li X., Neerathilingam M., Lokesh G. L., et al. (2010). Combinatorial Selection of DNA Thioaptamers Targeted to the HA Binding Domain of Human CD44. Biochemistry 49, 91069112. doi: 10.1021/bi1009503

Song Y., Song J., Wei X., Huang M., Sun M., Zhu L., et al. (2020). Discovery of Aptamers Targeting the Receptor-Binding Domain of the SARS-CoV-2 Spike Glycoprotein. Anal. Chem. 92, 9895-9900. doi: 10.1021/acs.analchem.0c01394 
Soundararajan S., Chen W., Spicer E. K., Courtenay-Luck N., and Fernandes D. J. (2008). The Nucleolin Targeting Aptamer AS1411 Destabilizes Bcl-2 Messenger RNA in Human Breast Cancer Cells. Cancer Res. 68, 2358-2365. doi: 10.1158/0008-5472.CAN-07-5723

Sreejit G., Ahmed A., Parveen N., Jha V., Valluri V. L., Ghosh S., et al. (2014). The ESAT-6 Protein of Mycobacterium Tuberculosis Interacts With beta-2microglobulin $(\beta 2 \mathrm{~m})$ Affecting Antigen Presentation Function of Macrophage. PloS Pathog. 10, e1004446. doi: 10.1371/journal.ppat.1004446

Srivastava S., Battu M. B., Khan M. Z., Nandicoori V. K., and Mukhopadhyay S. (2019). Mycobacterium Tuberculosis PPE2 Protein Interacts With p67phox and Inhibits Reactive Oxygen Species Production. J. Immunol. 203, 1218-1229. doi: 10.4049/jimmunol.1801143

Stoltenburg R., Reinemann C., and Strehlitz B. (2005). FluMag-SELEX as an Advantageous Method for DNA Aptamer Selection. Anal. Bioanal Chem. 383, 83-91. doi: 10.1007/s00216-005-3388-9

Stoltenburg R., Reinemann C., and Strehlitz B. (2007). SELEX-a (R)Evolutionary Method to Generate High-Affinity Nucleic Acid Ligands. Biomol. Eng 24, 381403. doi: 10.1016/j.bioeng.2007.06.001

Sun X., Pan Q., Yuan C., Wang Q., Tang X. L., Ding K., et al. (2016). A Single ssDNA Aptamer Binding to Mannose-Capped Lipoarabinomannan of Bacillus Calmette-Guérin Enhances Immunoprotective Effect Against Tuberculosis. J. Am. Chem. Soc 138, 11680-11689. doi: 10.1021/jacs.6b05357

Takahashi M., Sakota E., and Nakamura Y. (2016). The Efficient cell-SELEX Strategy, cell-SELEX, Using Isogenic Cell Lines for Selection and CounterSelection to Generate RNA Aptamers to Cell Surface Proteins. Biochimie 131, 77-84. doi: 10.1016/j.biochi.2016.09.018

Tang X. L., Wu S. M., Xie Y., Song N., Guan Q., Yuan C., et al. (2016). Generation and Application of ssDNA Aptamers Against Glycolipid Antigen ManLAM of Mycobacterium Tuberculosis for TB Diagnosis. J. Infect. 72, 573-586. doi: 10.1016/j.jinf.2016.01.014

Tang X. L., Zhou Y. X., Wu S. M., Pan Q., Xia B., and Zhang X. L. (2014). CFP10 and ESAT6 Aptamers as Effective Mycobacterial Antigen Diagnostic Reagents. J. Infect. 69, 569-580. doi: 10.1016/j.jinf.2014.05.015

Thomas L. (2020). Researchers Re-Purpose Cancer-Fighting Artificial Antibodies for COVID-19 (News-Medical.Net). Available at: https://www.news-medical. net/news/20200427/Researchers-re-purpose-cancer-fighting-artificialantibodies-for-COVID-19.aspx.

Toh S. Y., Citartan M., Gopinath S. C., and Tang T. H. (2015). Aptamers as a Replacement for Antibodies in Enzyme-Linked Immunosorbent Assay. Biosens Bioelectron 64, 392-403. doi: 10.1016/j.bios.2014.09.026

Trausch J. J., Shank-Retzlaff M., and Verch T. (2017). Development and Characterization of an HPV Type-16 Specific Modified DNA Aptamer for the Improvement of Potency Assays. Anal. Chem. 89, 3554-3561. doi: 10.1021/ acs.analchem.6b04852

Tuerk C., and Gold L. (1990). Systematic Evolution of Ligands by Exponential Enrichment: RNA Ligands to Bacteriophage T4 DNA Polymerase. Science 249, 505-510. doi: 10.1126/science.2200121

Tundup S., Pathak N., Ramanadham M., Mukhopadhyay S., Murthy K. J., Ehtesham N. Z., et al. (2008). The Co-Operonic PE25/PPE41 Protein Complex of Mycobacterium Tuberculosis Elicits Increased Humoral and Cell Mediated Immune Response. PloS One 3, e3586. doi: 10.1371/ journal.pone. 0003586

Vater A., Jarosch F., Buchner K., and Klussmann S. (2003). Short Bioactive Spiegelmers to Migraine-Associated Calcitonin Gene-Related Peptide Rapidly
Identified by a Novel Approach: Tailored- SELEX. Nucleic Acids Res. 31, e130. doi: $10.1093 /$ nar/gng130

Vater A., and Klussmann S. (2015). Turning Mirror-Image Oligonucleotides Into Drugs: The Evolution of Spiegelmer $\left({ }^{\circledR}\right)$ Therapeutics. Drug Discovery Today 20, 147-155. doi: 10.1016/j.drudis.2014.09.004

Vivekananda J., and Kiel J. L. (2006). Anti-Francisella Tularensis DNA Aptamers Detect Tularemia Antigen From Different Subspecies by Aptamer-Linked Immobilized Sorbent Assay. Lab. Invest. 86, 610-618. doi: 10.1038/labinvest.3700417

Wang K., Gan L., Jiang L., Zhang X., Yang X., Chen M., et al. (2015). Neutralization of Staphylococcal Enterotoxin B by an Aptamer Antagonist. Antimicrob. Agents Chemother. 59, 2072-2077. doi: 10.1128/AAC.04414-14

Wang J., Gong Q., Maheshwari N., Eisenstein M., Arcila M. L., Kosik K. S., et al. (2014). Particle Display: A Quantitative Screening Method for Generating High-Affinity Aptamers. Angew Chem. Int. Ed. Engl. 53, 4796-4801. doi: 10.1002/anie.201309334

Waters E. K., Genga R. M., Schwartz M. C., Nelson J. A., Schaub R. G., Olson K. A., et al. (2011).

World Health Organization (WHO) (2019). Global Tuberculosis Report.

Xu J. N., Chen J. P., and Chen D. L. (2012). Serodiagnosis Efficacy and Immunogenicity of the Fusion Protein of Mycobacterium Tuberculosis Composed of the 10-Kilodalton Culture Filtrate Protein, ESAT-6, and the Extracellular Domain Fragment of PPE68. Clin. Vaccine Immunol. 19, 536544. doi: 10.1128/CVI.05708-11

Ye H., Duan N., Gu H., Wang H., and Wang Z. (2019). Fluorometric Determination of Lipopolysaccharides Via Changes of the Graphene OxideEnhanced Fluorescence Polarization Caused by Truncated Aptamers. Mikrochim Acta 186, 173. doi: 10.1007/s00604-019-3261-8

Zhang H., Wang J., Lei J., Zhang M., Yang Y., Chen Y., et al. (2007). PPE Protein (Rv3425) From DNA Segment RD11 of Mycobacterium Tuberculosis: A Potential B-cell Antigen Used for Serological Diagnosis to Distinguish Vaccinated Controls From Tuberculosis Patients. Clin. Microbiol. Infect. 13, 139-145. doi: 10.1111/j.1469-0691.2006.01561.x

Zhang H., Wang Z., Xie L., Zhang Y., Deng T., Li J., et al. (2018). Molecular Recognition and In Vitro-Targeted Inhibition of Renal Cell Carcinoma Using a DNA Aptamer. Mol. Ther. Nucleic Acids 12, 758-768. doi: 10.1016/ j.omtn.2018.07.015

Zhou J., Li H., Zhang J., Piotr S., and Rossi J. (2011). Development of Cell-Type Specific anti-HIV gp120 Aptamers for siRNA Delivery. J. Vis. Exp. 52, 29542962. doi: $10.3791 / 2954$

Zhu C., Liu J., Ling Y., Yang H., Liu Z., Zheng R., et al. (2012). Evaluation of the Clinical Value of ELISA Based on MPT64 Antibody Aptamer for Serological Diagnosis of Pulmonary Tuberculosis. BMC Infect. Dis. 12, 96. doi: 10.1186/ 1471-2334-12-96

Conflict of Interest: The authors declare that the research was conducted in the absence of any commercial or financial relationships that could be construed as a potential conflict of interest.

Copyright () 2021 Srivastava, Abraham and Mukhopadhyay. This is an open-access article distributed under the terms of the Creative Commons Attribution License (CC BY). The use, distribution or reproduction in other forums is permitted, provided the original author(s) and the copyright owner(s) are credited and that the original publication in this journal is cited, in accordance with accepted academic practice. No use, distribution or reproduction is permitted which does not comply with these terms. 